\title{
Flavopereirine Suppresses the Growth of Colorectal Cancer Cells through P53 Signaling Dependence
}

\author{
Jhy-Ming Li ${ }^{1,2}$, Yun-Ching Huang ${ }^{3}{ }^{-}$, Yi-Hung Kuo ${ }^{1,2}$, Chih-Chung Cheng ${ }^{2}$, Feng-Che Kuan ${ }^{2,4}$, \\ Shun-Fu Chang ${ }^{5}$, Ying-Ray Lee ${ }^{6}\left(\mathbb{B}\right.$, Chih-Chien Chin ${ }^{1, *}$ and Chung-Sheng Shi $1,2,3, * \mathbb{C}$ \\ 1 Division of Colon and Rectal Surgery, Department of Surgery, Chang Gung Memorial Hospital, \\ Chiayi 61363, Taiwan ${ }^{2}$ Graduate Institute of Clinical Medical Sciences, College of Medicine, Chang Gung \\ University, Taoyuan 33302, Taiwan ${ }^{3}$ Division of Urology, Department of Surgery, Chang Gung Memorial \\ Hospital, Chiayi 61363, Taiwan \\ 4 Department of Hematology and Oncology, Department of Medicine, Chang Gung Memorial Hospital, \\ Chiayi 61363, Taiwan \\ 5 Department of Medical Research and Development, Chang Gung Memorial Hospital Chiayi Branch, \\ Chiayi 61363, Taiwan \\ 6 Department of Medical Research, Ditmanson Medical Foundation Chia-Yi Christian Hospital, \\ Chiayi 60002, Taiwan \\ * Correspondence: ccchin@cgmh.org.tw (C.-C.C.); csshi@mail.cgu.edu.tw (C.-S.S.); \\ Tel.: +886-5-3621000 (ext. 2752) (C.-C.C.); +886-5-3621000 (ext. 2100) (C.-S.S.); \\ Fax: $+886-5-3623002$ (C.-C.C.); $+886-3-2118700$ (C.-S.S.)
}

Received: 10 June 2019; Accepted: 19 July 2019; Published: 22 July 2019

\begin{abstract}
Colorectal cancer (CRC) is a significant cause of morbidity and mortality worldwide. The outcome of CRC patients remains poor. Thus, a new strategy for CRC treatment is urgently needed. Flavopereirine is a $\beta$-carboline alkaloid extracted from Geissospermum vellosii, which can reduce the viability of various cancer cells through an unknown mode of action. The aim of the present study was to investigate the functional mechanism and therapeutic potential of flavopereirine on CRC cells in vitro and in vivo. Our data showed that flavopereirine significantly lowered cellular viability, caused intrinsic and extrinsic apoptosis, and induced G2/M-phase cell cycle arrest in CRC cells. Flavopereirine downregulated Janus kinases-signal transducers and activators of transcription (JAKs-STATs) and cellular myelocytomatosis (c-Myc) signaling in CRC cells. In contrast, the enforced expressions of constitutive active STAT3 and c-Myc could not restore flavopereirine-induced viability reduction. Moreover, flavopereirine enhanced P53 expression and phosphorylation in CRC cells. CRC cells with P53 knockout or loss-of-function mutation significantly diminished flavopereirine-mediated viability reduction, indicating that P53 activity plays a major role in flavopereirine-mediated CRC cell growth suppression. Flavopereirine also significantly repressed CRC cell xenograft growth in vivo by upregulating P53 and P21 and inducing apoptosis. In conclusion, flavopereirine-mediated growth suppression in CRC cells depended on the P53-P21, but not the JAKs-STATs-c-Myc signaling pathway. The present study suggests that flavopereirine may be efficacious in the clinical treatment of CRC harboring functional P53 signaling.
\end{abstract}

Keywords: colorectal cancer; Flavopereirine; P53

\section{Introduction}

High-grade colorectal cancer (CRC) is a major cause of morbidity and mortality worldwide [1]. Though advances have been made in current therapeutic approaches, their benefits are limited in clinical practice [2,3]. Thus, searching for a new strategy for CRC treatment is urgently needed. The pathogenetic mechanisms underlying CRC development and progression are complex and heterogeneous $[4,5]$. 
Risk factors in CRC development include the influences of early-stage adenomatous polyposis coli (APC) mutations [6] and late-stage tumor suppressor $p 53$ and $K$-ras mutations on malignant epithelial-mesenchymal phenotype transformation [7].

Various signaling pathways such as Janus kinases-signal transducers and activators of transcription (JAKs-STATs) participate in CRC progression [8]. When cytokines bind to their receptors, JAKs and STATs are recruited and phosphorylated, resulting in the nuclear translocation of dimerized STATs and the expression of downstream mediators [9]. The four mammalian JAK family members are JAK1, JAK2, JAK3, and Tyrosine Kinase 2. They selectively phosphorylate and activate STATs [10]. Moreover, certain growth factor receptors also induce STATs by promoting intrinsic tyrosine-kinase activation including the epidermal growth factor [11], G-protein-coupled, and Toll-like [9] receptors. STAT1, STAT2, STAT3, STAT4, STAT5a, STAT5b, and STAT6 are also identified in mammalian cells [12]. Of these, STAT3 has been studied the most. It increases tumor cell proliferation, differentiation, metastasis, and angiogenesis by stimulating tumor-promoting inflammation [13]. STAT3 activation is also involved in CRC tumorigenesis [14]. It regulates B-cell lymphoma 2 (Bcl-2), Myeloid cell leukemia-1 (Mcl-1), and cellular myelocytomatosis (c-Myc) expression to maintain cell survival and proliferation $[15,16]$. Specific siRNAs or small molecular inhibitor of STAT3 can sensitize CRC cells to chemoradiotherapy in vitro and in vivo [17].

P53 plays an important role in the cellular stress response pathways for responding to DNA damage and repair, apoptosis, and senescence $[18,19]$. It transcriptionally activates downstream genes for inducing cell cycle arrest and apoptosis [20,21]. P53 is upregulated and its phosphorylation increases in response to DNA damage. This increased P53 activity regulates P21 expression, induces cell cycle arrest, interferes with DNA replication, and repairs DNA breaks [22]. Several P53-dependent target genes, including $p 21$ and $b a x$, are identified by sequence-specific transcriptional analysis [23]. P53 can bind directly to Bcl-2 and B-cell lymphoma-extra large (Bcl-XL), which prevents their mitochondrial translocation via losing out mitochondrial membrane integrity and releases cytochrome $c$ for inducing cellular apoptosis [24]. Moreover, $p 53$ mutation is frequently associated with poor clinical outcomes in various human malignancies [25]. In CRC, it is observed in $~ 40 \%$ to $50 \%$ of all CRC cases [19] and causes tumor progression and treatment resistance. Thus, targeting and restoring P53 activity are promising tumor therapy enhancement strategies [26-28].

Flavopereirine (3-ethyl-12H-indolo[2,3-a]-quinolizinium perchlorate) is a natural $\beta$-carboline alkaloid extracted from Geissospermum vellosii (Pao pereira) [29]. A previous study shows that flavopereirine selectively inhibits DNA synthesis in cancer cells [30]. The anticancer agent PB-100 which contains flavopereirine and dihydroflavopereirine, selectively inhibits the proliferation of CRC cells but not their normal counterparts [31]. Flavopereirine lowers the viability of drug-resistant glioblastoma cells and suppresses their IL-6-activated proliferation [32,33]. However, the mechanisms and in vivo therapeutic efficacy of flavopereirine in CRC cells are unknown. In the present study, the mode of action and therapeutic potential of flavopereirine in the suppression CRC cell growth via the P53-P21 and JAKs-STATs-cMyc signal pathways were evaluated in vitro and in vivo.

\section{Results}

\subsection{Flavopereirine Reduces the Viability of Certain CRC Cell Lines}

PB100 suppresses the proliferation of CRC cells, but not normal cells [31]. However, the molecular mechanism of flavopereirine in CRC cell growth remains unknown. Here, we investigated the effects of flavopereirine on the viability of various malignant stages of the CRC cell lines SW1116 (Duke's stage A), SW480 (Duke's stage B), DLD1, SW620 (Duke's stage C), HCT116 (Duke's stage D), and HT29 (no informative Duke's stage). Figure 1A shows that flavopereirine significantly lowered the viability of SW480, SW620, DLD1, HCT116, and HT29 cells ( $\mathrm{IC}_{50} 58.61,30.99,32.37,19.66$, and $21.06 \mu \mathrm{M}$, respectively) after $24 \mathrm{~h}$, but had no significant influence on early-stage SW1116 cells. Figure 1B shows that after $48 \mathrm{~h}$ treatment with flavopereirine, SW480, SW620, DLD1, HCT116, and HT29 cell viability 
were significantly reduced ( $\mathrm{IC}_{50} 15.33,10.52,10.76,8.15$, and $9.58 \mu \mathrm{M}$, respectively). In contrast, it only slightly affected that of SW1116 cells. Moreover, beside HCT116 cells, SW480, SW620, DLD1 and HT29 were relatively resistant to oxaliplatin treatment in the viability assay (Supplementary Figure S1A,B). However, they were very sensitivity to flavopereirine. Thus, flavopereirine may potentially suppress the relatively more malignant and drug-resistant CRC cell lines.

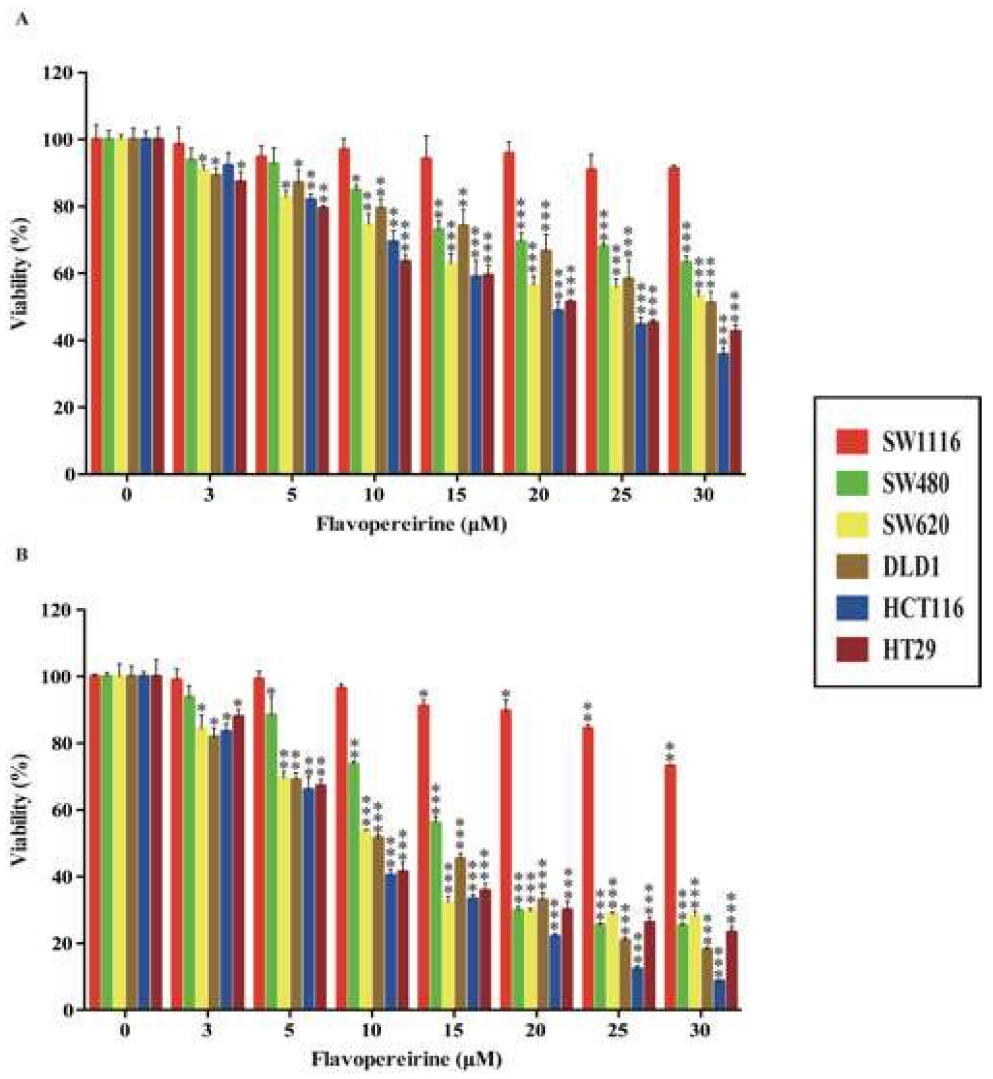

Figure 1. Flavopereirine lowered the viability of various CRC cell lines. CRC cells were treated with various concentrations of flavopereirine for $24 \mathrm{~h}$ and $48 \mathrm{~h}$ and their viability was assayed by CCK8. Values were expressed as cell viability [\%]. Each value represented the mean $\pm \mathrm{SD}$ of quadruplicate assays. ${ }^{*} p<0.05 ;{ }^{* *} p<0.01,{ }^{* * *} p<0.001$ compared with the control. Similar results were obtained for at least three independent experiments.

\subsection{Flavopereirine Promotes Intrinsic and Extrinsic Apoptosis in CRC Cells}

As flavopereirine reduced the viability of certain malignant CRC cells, we examined the apoptotic effect of flavopereirine on the most sensitive cell lines. Figure 2A shows that flavopereirine markedly increased both early and late apoptosis in HCT116 and DLD1 after $24 \mathrm{~h}$ and $48 \mathrm{~h}$ exposure. HCT116 cells were more sensitive to flavopereirine than DLD1 cells in terms of apoptosis induction. Nevertheless, the mechanism involved has not yet been elucidated.

As flavopereirine induced apoptosis in CRC cells, we attempted to determine its underlying mode of action. Figure 2B shows that flavopereirine enhanced the cleavage of caspase-3, -8 , and -9 , and poly (ADP-ribose) polymerase (PARP) in HCT116 and DLD1 cells after $24 \mathrm{~h}$ and $48 \mathrm{~h}$ exposure in a dose-dependent manner. Moreover, the pro-survival Bcl-2 family proteins Mcl-1 and Bcl-2 were downregulated after $24 \mathrm{~h}$ and $48 \mathrm{~h}$ flavopereirine treatment (Figure 2C). In contrast, the expression of $\mathrm{Bcl}-2$ interacting killer (Bik) (the alternate splicing of Bcl-2-like protein $11(\mathrm{Bim})$ ) and the truncation of BH3 interacting-domain death agonist (Bid) (pro-apoptotic) were upregulated after $24 \mathrm{~h}$ and $48 \mathrm{~h}$ flavopereirine treatment (Figure 2D). Figure 2A-D demonstrate that flavopereirine induced CRC cell apoptosis via intrinsic and extrinsic pathways in a dose-dependent manner. 
A

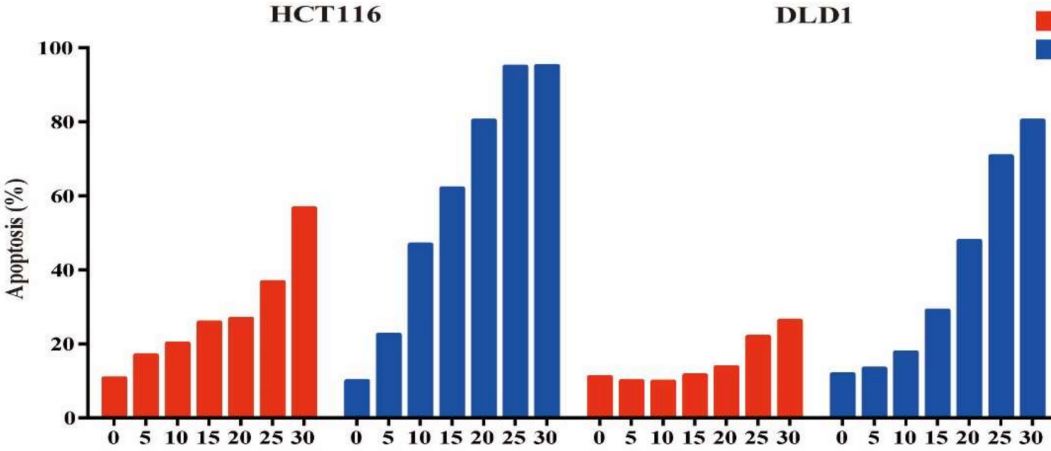
Flavopereirine $(\mu \mathrm{M})$

B
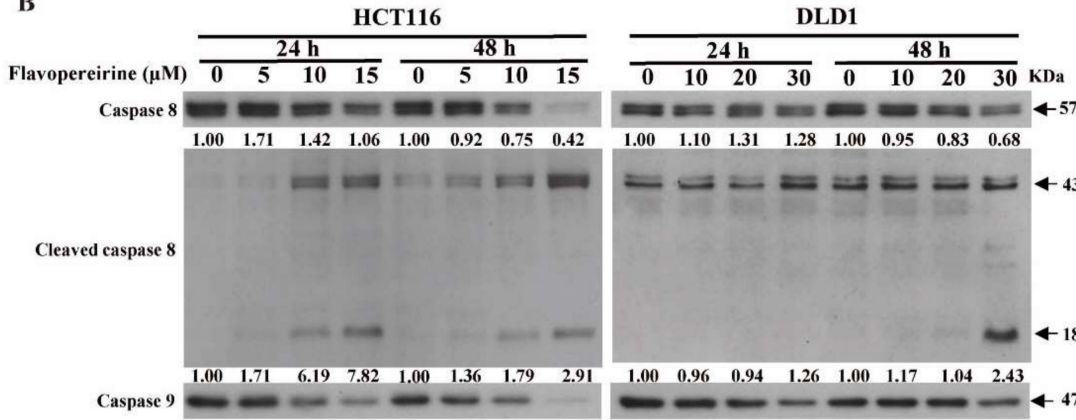

$\begin{array}{llllllll}1.00 & 1.10 & 1.31 & 1.28 & 1.00 & 0.95 & 0.83 & 0.68\end{array}$

$\begin{array}{lllllllll}1.00 & 1.11 & 1.45 & 0.72 & 1.00 & 0.96 & 0.76 & 0.40\end{array}$

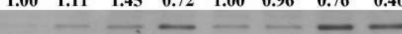

\begin{tabular}{llllllll}
1.00 & 3.60 & 6.43 & 11.61 & 1.00 & 0.98 & 3.03 & 2.81 \\
\hline & & & & & & &
\end{tabular}

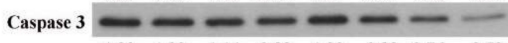

$\begin{array}{llllllll}1.00 & 1.00 & 1.14 & 0.89 & 1.00 & 0.82 & 0.76 & 0.59\end{array}$

$=- \pm=- \pm=-43$

Cleaved caspase 3

$\begin{array}{llllllll}1.00 & 3.15 & 7.59 & 12.32 & 1.00 & 1.81 & 2.93 & 6.74\end{array}$

PARP $=-\infty=-\infty .00$

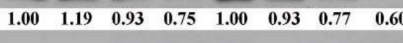

Cleaved PARP

$\begin{array}{lllllllll}1.00 & 1.00 & 1.71 & 24.05 & 1.00 & 2.95 & 48.82 & 63.51\end{array}$

B-actin

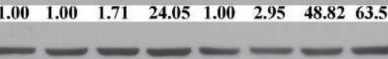
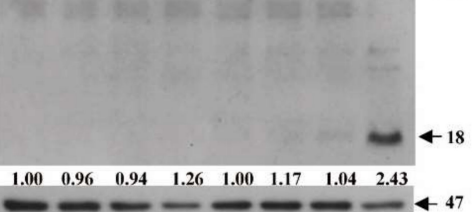

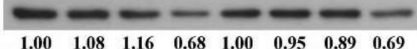

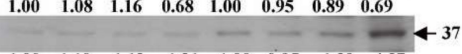

\begin{tabular}{llllllll}
1.00 & 1.10 & 1.12 & 1.21 & 1.00 & 0.95 & 1.39 & 4.37 \\
\hline
\end{tabular}

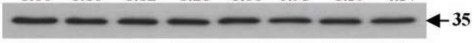

$\begin{array}{llllllll}1.00 & 1.16 & 1.25 & 1.24 & 1.00 & 0.85 & 0.94 & 0.87\end{array}$
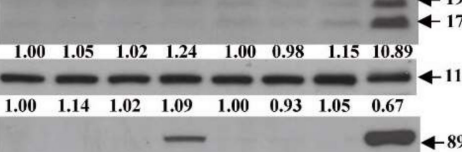

$\begin{array}{llllllll}1.00 & 1.00 & 1.00 & 21.41 & 1.00 & 1.00 & 1.00 & 60.09\end{array}$

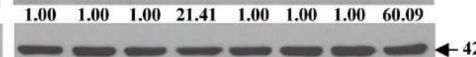

C
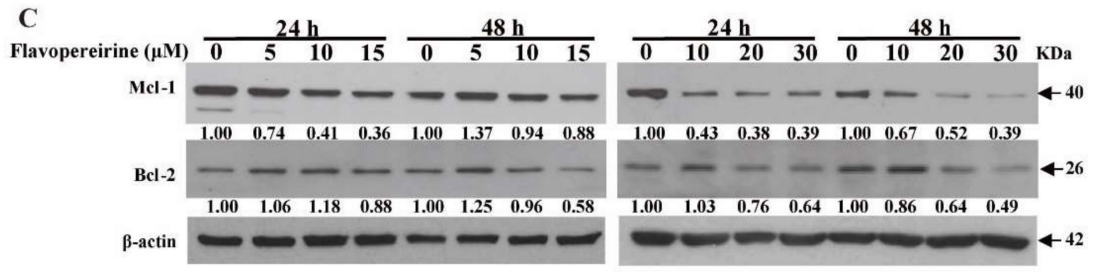

D
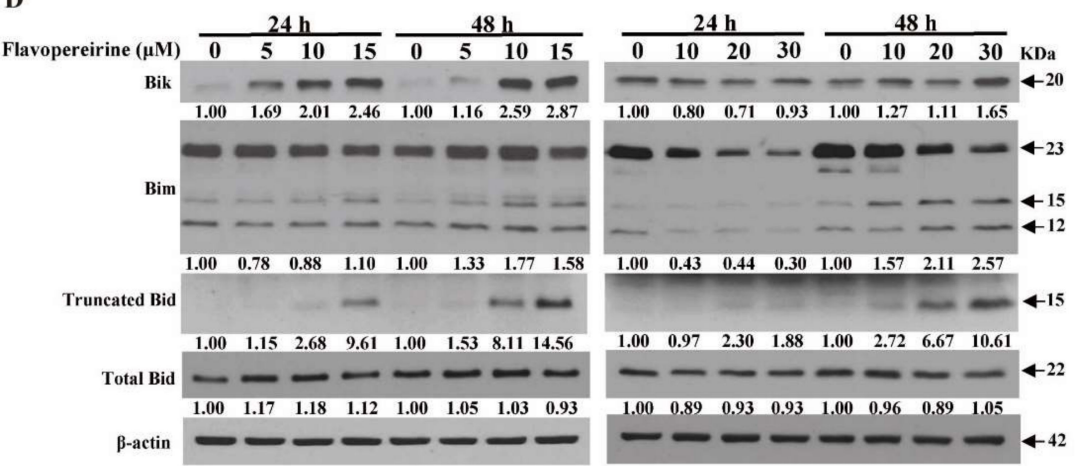

Figure 2. Flavopereirine induced both extrinsic and intrinsic apoptosis in CRC cells

Flavopereirine-induced apoptosis in HCT116 and DLD1 cells was assayed and quantified after $24 \mathrm{~h}$ and $48 \mathrm{~h}$ treatment. (B) Flavopereirine promoted the cleavage of caspase-8, -9, and -3 and PARP. (C,D) Flavopereirine downregulated the pro-survival Bcl-2 family proteins and upregulated the pro-apoptotic proteins $\mathrm{Mcl}-1$, Bcl-2, Bik, Bim, and Truncated Bid. Numbers under the plots indicate the fold change of protein level relative to their untreated control. Similar results were obtained in at least three independent experiments. 


\subsection{Flavopereirine Stimulates G2/M-Phase Cell Cycle Arrest in CRC Cells}

Flavopereirine significantly constrained CRC cell viability. Thus, we assessed whether flavopereirine affected cell cycle progression. Figure $3 \mathrm{~A}, \mathrm{~B}$ indicate that flavopereirine caused G2/M-phase cell cycle accumulation in HCT116 and DLD1 cells after $24 \mathrm{~h}$ treatment. An earlier study reports that P53-dependent P21 upregulation regulates G2-phase cell cycle progression by preventing the formation of the cell division control protein 2 /cyclin B1 complex [34]. Figure 3C discloses that flavopereirine upregulated the expression and Ser-15 phosphorylation of P53, indicating flavopereirine upregulated P53 activity to control cell cycle arrest. Moreover, flavopereirine enhanced P21 expression and diminished that of the G2/M regulatory cyclin B1. Furthermore, the Ser-10 phosphorylation of histone $\mathrm{H} 3$ involves in regulating G2/M progression [35]. Consistently, flavopereirine decreased $\mathrm{pHH} 3$ in HCT116 and DLD1 cells. These data (Figure 3) indicate that flavopereirine may upregulate P53 activity to prevent G2/M transition by increasing P21, decreasing intracellular cyclin B1, attenuating $\mathrm{HH} 3$ activity and resulting in arresting the G2/M-phase cell cycle.
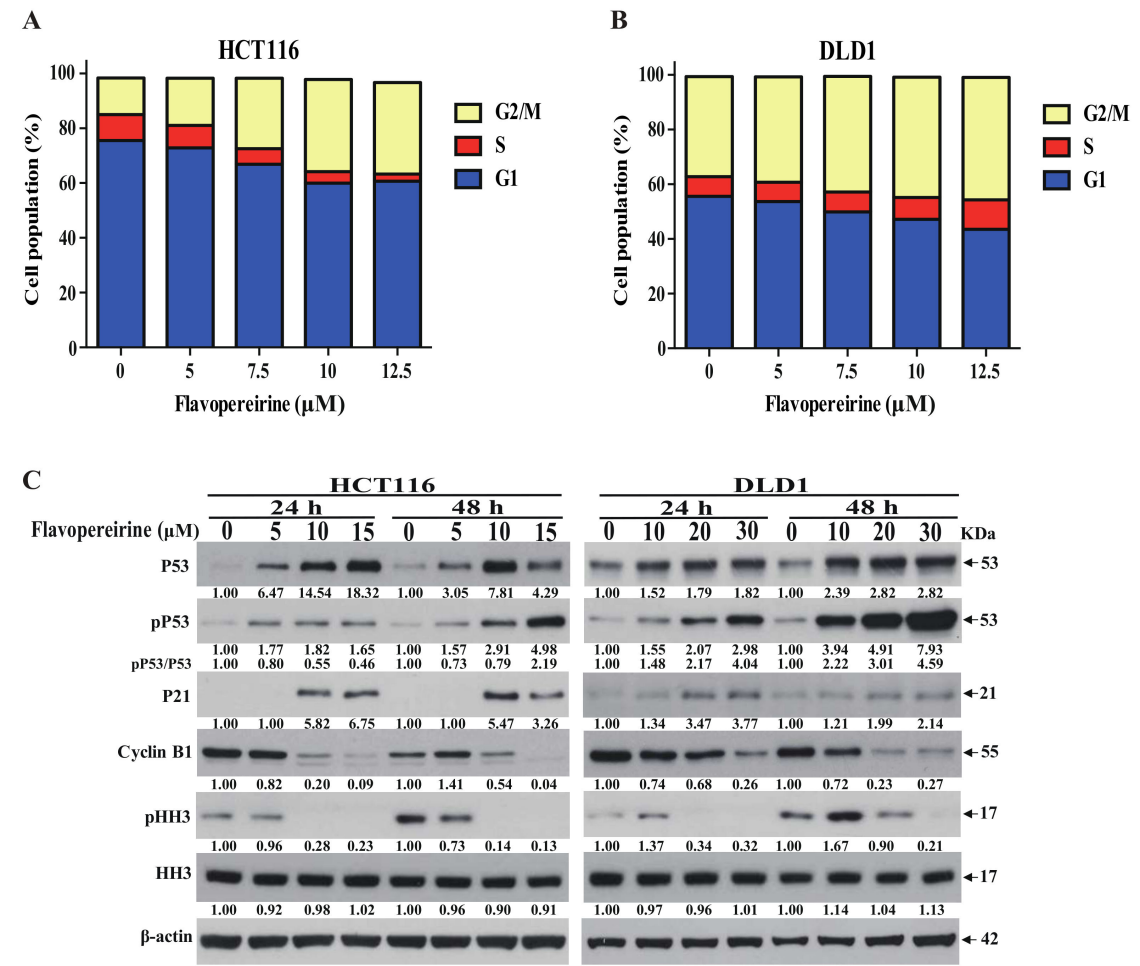

Figure 3. Flavopereirine induced G2/M-phase cell cycle arrest. (A) The cell cycle distributions of HCT116 and DLD1 were assayed and quantified after flavopereirine treatment for $24 \mathrm{~h}$. Values were expressed as cell population [\%]. (B) Flavopereirine upregulated P53 and P21 expression and phosphorylation, downregulated cyclin B1, and diminished the phosphorylation of histone H3 after 24 $\mathrm{h}$ and $48 \mathrm{~h}$ treatment. Numbers under the plots indicate the fold change of protein level relative to their untreated control. Similar results were obtained for at least three independent experiments.

\subsection{Flavopereirine Lowers CRC Cell Viability via JAKs-STATs-c-Myc Signaling but Is Not Dependent on It}

The JAKs/STATs pathway is involved in CRC progression [14]. For this reason, the effects of flavopereirine on JAKs-STATs-c-Myc signaling were examined. Figure 4A shows that the phosphorylation of JAK2, STAT1, and STAT3 and the expression of downstream c-Myc protein were suppressed in a dose-dependent manner after $24 \mathrm{~h}$ and $48 \mathrm{~h}$ flavopereirine treatment. Therefore, the JAK2-STAT1/STAT3-cMyc signal axis might participate in the flavopereirine-induced reduction of CRC cell viability. The importance of this signaling pathway was underscored by inducing the expression of constitutive active STAT3 and c-Myc in CRC cells. The stable transfection of constitutive 
active stat3 (cstat3) increased STAT3 expression and phosphorylation (Figure 4B). However, constitutive active STAT3 expression did not reverse the reduction of CRC cell viability by flavopereirine treatment (Figure 4C). Moreover, the transient transfection of $c$-myc strongly upregulated c-Myc (Figure 4D). On the other hand, enforced c-Myc expression failed to reverse the reduction of CRC cell viability by flavopereirine treatment as well (Figure 4E). Figure 4 reveals that flavopereirine lowered CRC cell viability through the JAKs-STATs-c-Myc pathway, but was independent of STAT3-c-Myc signaling.
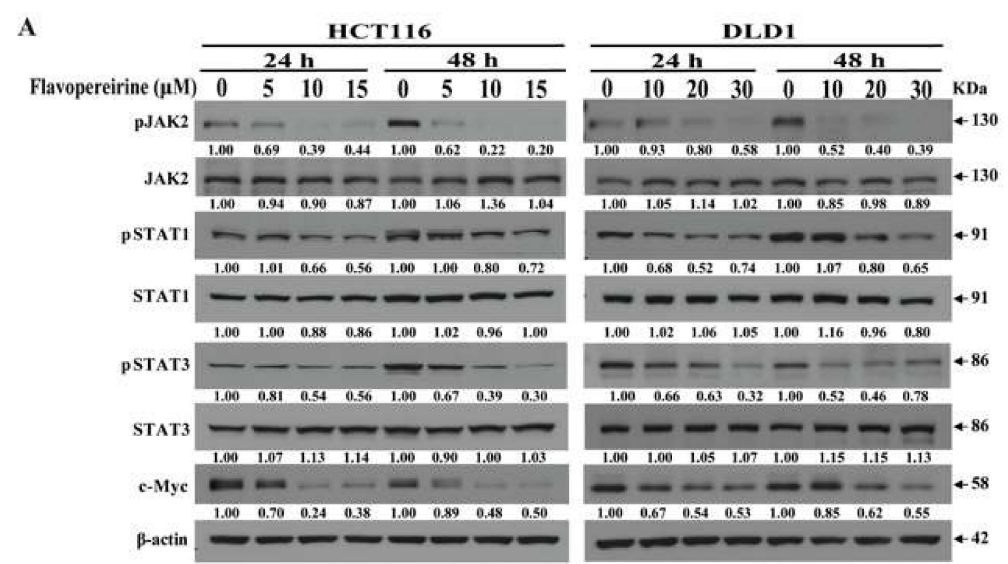

B
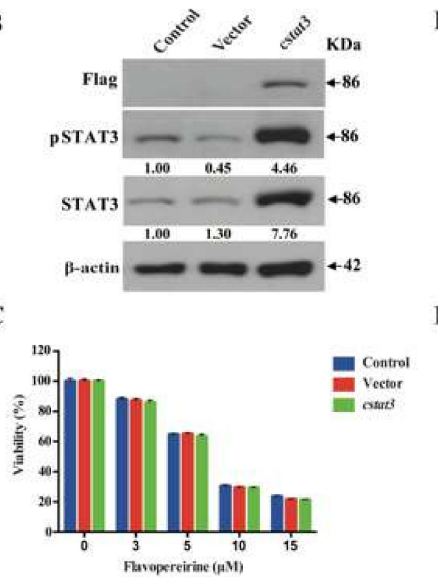


Figure 4. Flavopereirine non-dependently utilized STAT3/c-Myc signaling to reduce CRC cell viability. (A) Phosphorylation of JAK2, STAT1 and STAT3 and expression of downstream c-Myc protein were suppressed in a dose-dependent manner after treatment with flavopereirine for $24 \mathrm{~h}$ and $48 \mathrm{~h}$. $(\mathbf{B}, \mathrm{D})$ STAT3 and c-Myc proteins were strongly upregulated by introducing cstat 3 and c-myc into CRC cells at $48 \mathrm{~h}$. (C,E) The enforced expressions of STAT3 and c-Myc did not reverse flavopereirine-mediated viability reduction in CRC cells. Numbers under the plots indicate the fold change of protein level relative to their untreated control. Similar results were obtained for at least three independent experiments.

2.5. P53 Signaling Is Involved in Flavopereirine-Mediated Viability Reduction and Apoptosis Induction in CRC Cells

P53 expression and activity play important roles in restricting malignant cell growth by inducing cell cycle arrest and apoptosis [36]. Flavopereirine increased P53 expression and phosphorylation in CRC cells in a dose-dependent manner. Here, we verified the functional involvement of P53 in the suppression of CRC cell viability by flavopereirine treatment. To this end, we used wild type HCT116 $\left(p 53^{+/+}\right)$, isogenic $p 53$ knockout HCT116 $\left(p 53^{-/-}\right)$, and P53-expressing $\mathrm{CaCO}_{2}$ which generates a nonfunctional, undetectable truncated $\mathrm{P} 53$ protein due to a UAG nonsense mutation at codon 204 of $p 53$ gene [37]. Figure 5A shows that HCT116 ( $\left.p 53^{-/-}\right)$and $\mathrm{CaCO}_{2}$ cells were more resistant to flavopereirine than HCT116 $\left(p 53^{+/+}\right)$cells after $48 \mathrm{~h}$ treatment. Therefore, functional P53 expression is vital in flavopereirine-mediated CRC cell growth suppression. 

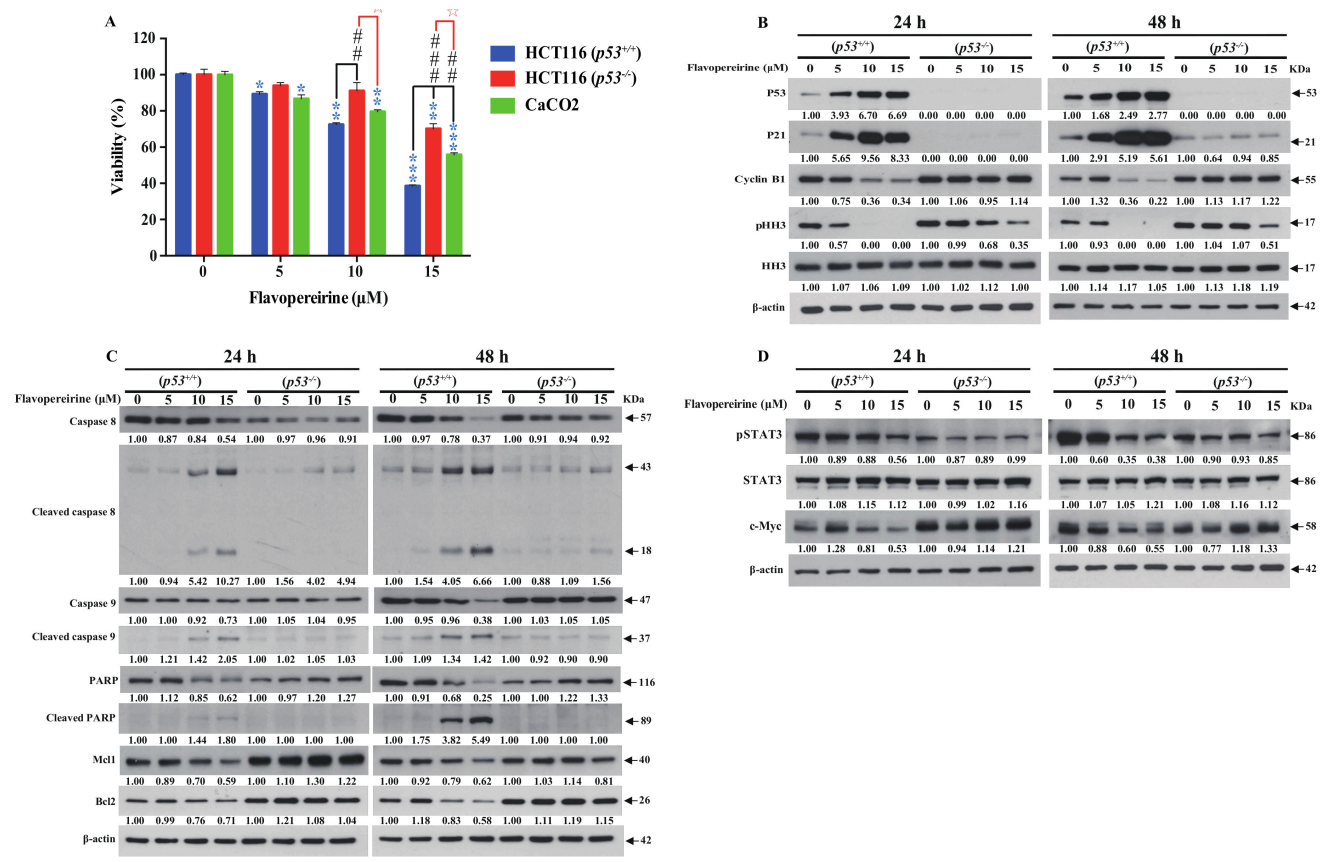

Figure 5. P53 signaling participated in flavopereirine-mediated viability reduction and apoptosis induction. HCT116 $p 53^{+/+}, p 53^{-/-}$and $\mathrm{CaCO}_{2}$ cells were treated with flavopereirine for $48 \mathrm{~h}$. (A) Cell viability was determined by CCK8 assay. Each value was the mean \pm SD of quadruplicate assays. ${ }^{*} p<0.05 ;{ }^{* *} p<0.01,{ }^{* * *} p<0.001$ compared to each untreated control. ${ }^{\# \#} p<0.01$ and ${ }^{\# \# \#} p<0.001$ compared to flavopereirine $(10$ or $15 \mu \mathrm{M})$ treated HCT116 $\left(p 53^{+/+}\right)$group. is $p<0.05$ and is $p<$ 0.01 compared to flavopereirine $(10$ or $15 \mu \mathrm{M})$ treated HCT116 $\left(p 53^{-/-}\right)$group. (B-D) Pro-apoptotic, anti-survival, G2/M-phase cell cycle, and STAT3 signaling were not changed in HCT116 $\left(p 53^{-/-}\right)$cells relative to wild type HCT116 $\left(\mathrm{p53}^{+/+}\right)$cells after flavopereirine treatment for $24 \mathrm{~h}$ and $48 \mathrm{~h}$. Numbers under the plots indicate the fold change of protein level relative to their untreated control. Similar results were obtained in at least three independent experiments.

Flavopereirine upregulated P21 and downregulated cyclin B1 in HCT116 $\left(p 53^{+/+}\right)$cells, but not in HCT116 $\left(p 53^{-/-}\right.$) or $\mathrm{CaCO}_{2}$ cells (Figure 5B and Supplementary Figure S2A). Thus, p53-dependent p21 upregulation is crucial in flavopereirine-mediated G2/M-phase cell cycle arrest. Moreover, flavopereirine-activated apoptosis was induced in HCT116 $\left(p 53^{+/+}\right)$cells, but not in HCT116 $\left(p 53^{-/-}\right)$ or $\mathrm{CaCO}_{2}$ cells (Figure 5C and Supplementary Figure S2B). Flavopereirine also suppressed STAT3 phosphorylation and c-Myc expression in HCT116 $\left(p 53^{+/+}\right)$cells, but not in HCT116 $\left(p 53^{-/-}\right)$or $\mathrm{CaCO}_{2}$ cells (Figure 5D and Supplementary Figure S2C). Figure 5 and Supplementary Figure S2 demonstrate that functional P53-not the JAKs-STATs-c-Myc signaling axis-regulates flavopereirine-mediated growth suppression. Interesting, $\mathrm{HH} 3$ phosphorylation was decreased, but not entirely repressed, in HCT116 $\left(\mathrm{p53}^{-/-}\right.$) or $\mathrm{CaCO}_{2}$ cells (Figure 5B and Supplementary Figure S2A), implying an independent mechanism of flavopereirine-mediated $\mathrm{HH} 3$ phosphorylation during $\mathrm{G} 2 / \mathrm{M}$-phase cell cycle progression.

\subsection{Flavopereirine Significantly Inhibits HCT116-Xenograft Tumor Growth In Vivo}

Flavopereirine significantly affected CRC cell viability. For this reason, the therapeutic efficacy of flavopereirine on HCT116 xenograft tumor growth was studied in vivo. Figure 6A depicts HCT116 xenograft tumorsFigure $6 \mathrm{~B}, \mathrm{C}$ reveal that flavopereirine substantially suppressed HCT116 xenograft tumor growth according to tumor volume and weight after three weeks of flavopereirine treatment. Figure 6D,E disclose that P53 and P21 were markedly upregulated in HCT116 xenograft tumors treated with flavopereirine compared with those subjected to phosphate-buffered saline (PBS; control). We also examined TUNEL (terminal deoxynucleotidyl transferase dUTP nick end labeling)-stained cells inside the tumors. These are indicative of apoptosis. Figure $6 \mathrm{~F}$ shows that relative to the PBS-treated controls, 
flavopereirine significantly enhanced apoptosis in HCT116 xenograft tumors. Furthermore, the effect of flavopereirine on normal colon tissue in vivo was also examined. By consulting with pathologist, Supplementary Figure S3 shows that the structure of colon wall was intact without significant morphological alternation and the infiltration of inflammatory cells within the colon wall was not found after flavopereirine treatment in mouse colon tissue in vivo, indicating the specific toxicity of flavopereirine on CRC cells rather than normal colon cells. The in vivo assay results presented in Figure 6 were consistent with those obtained and reported for the in vitro data, namely, flavopereirine-mediated CRC growth inhibition proceeds via P53-P21 signaling and apoptosis induction.

A

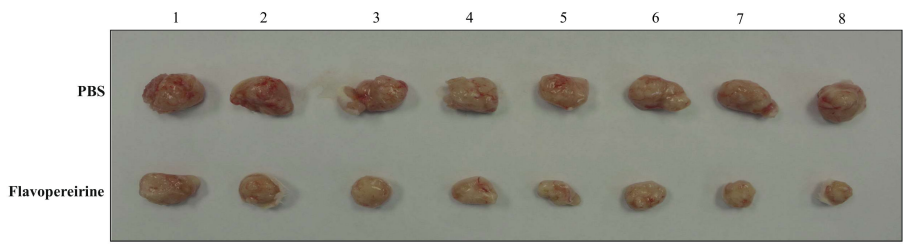

B

C

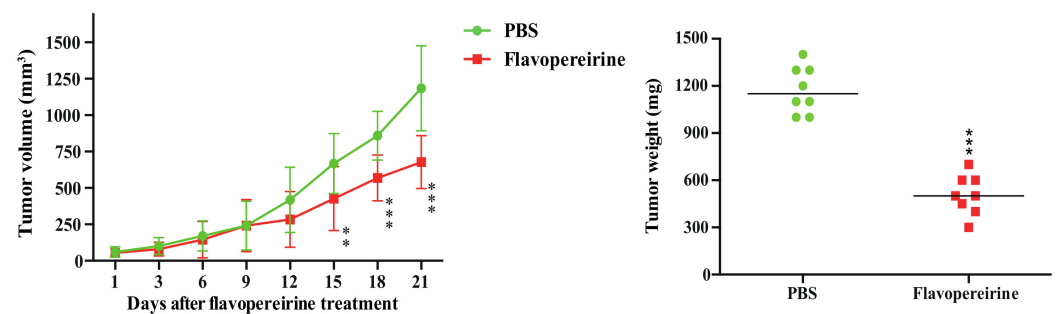

D

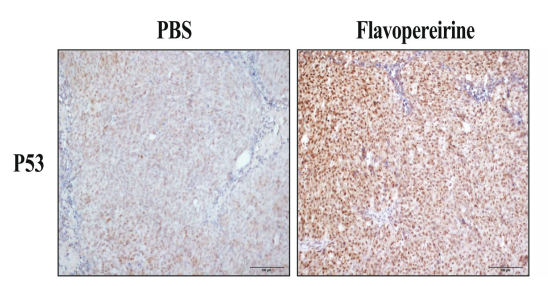

E

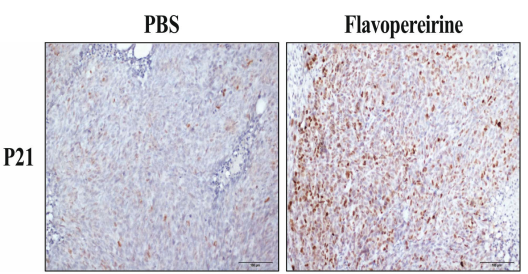

F

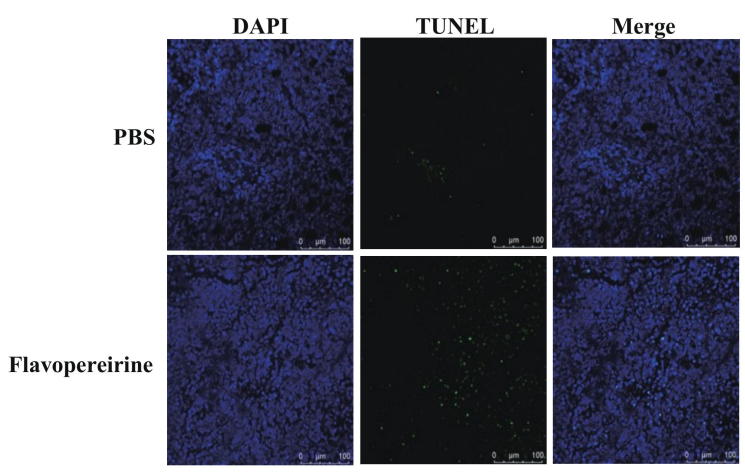

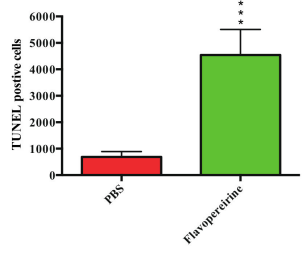

Figure 6. Flavopereirine significantly inhibited in vivo HCT116-xenograft growth. HCT116-bearing mice were treated either with PBS $(n=8)$ or flavopereirine $\left(10 \mathrm{mg} \mathrm{kg}^{-1} \mathrm{~d}^{-1}\right)(n=8)$. (A) Representative images of excised tumors from each group. (B) Tumor volumes were measured to reflect tumor growth. ${ }^{* *} p<0.01,{ }^{* * *} p<0.001$ compared with PBS. (C) Tumor weights were compared on the last day of treatment. ${ }^{* *} p<0.001$ compared with PBS. (D,E) P53 and P21 expression levels in HCT116 tumors were evaluated by immunohistochemical staining. Scale bar: $100 \mu \mathrm{m}$. (F) Apoptosis in HCT116 tumors was measured by TUNEL staining. ${ }^{* *} p<0.001$ compared with PBS. Scale bar: $100 \mu \mathrm{m}$. 


\section{Discussion}

CRC is an aggressive malignant tumor associated with high global mortality [38]. Surgery and chemotherapy are first-line treatments, but patients nonetheless present with recurrences and metastasis [39,40]. Therefore, low-toxicity, highly efficacious therapeutic agent are urgently needed for CRC. The present study demonstrated that flavopereirine markedly suppressed CRC cell growth in a dose-dependent manner via P53-, but not JAKs-STATs-c-Myc-dependent signaling. This mechanism arrested the G2/M-phase cell cycle and promoted apoptosis.

Our data also revealed that flavopereirine reduced CRC cell viability at the more highly malignant stages. This finding was consistent with that reported for a previous study in which the flavopereirine-based agent PB100 inhibited the proliferation of various malignant cells, but not normal cells [31]. The reason might be due to the flavopereirine preferentially impeding the initiation of DNA synthesis [30] during the growth of highly proliferative cancer cells rather than normal cells or slow-growing tumor cells.

The P53 and JAKs-STATs-c-Myc signals are significantly involved in CRC cell growth [41]. However, it is not understood why flavopereirine functions are mostly P53-dependent rather than STAT3- or c-Myc-dependent, as P53 is upstream of the latter two. An earlier work [30] reports that $\beta$-carboline alkaloids including flavopereirine selectively repress DNA synthesis in vitro by forming alkaloid-DNA complexes with cancer cells, but not with normal cells. This complex inhibits synthesis rather than chain elongation in cancer cell DNA [30]. P53 causes cell cycle arrest in response to DNA damage. It also interferes with DNA replication by directly interacting with the DNA replication machinery [42]. These results [30,42] imply that by hindering the initiation of DNA synthesis in CRC cells, flavopereirine may upregulate P53 activity, and trigger cell growth arrest, apoptosis induction, and the downregulation of survival signals including JAKs-STATs-c-Myc. This mechanism functionally restrains the growth of CRC and other cancer cells. Furthermore, STAT3 phosphorylation and c-Myc expression were diminished in HCT116 $\left(p 53^{+/+}\right)$but not in HCT116 $\left(p 53^{-/-}\right)$or $\mathrm{CaCO}_{2}$ cells after flavopereirine treatment, indicating P53 is upstream of JAKs-STATs-c-Myc signaling. P53 upregulation by the flavopereirine-DNA complex might be largely responsible for the suppression of CRC cell growth. However, the molecular mechanism by which the flavopereirine-cancer DNA complex promotes P53 expression remains to be elucidated.

Flavopereirine treatment strongly upregulated P53, but its mode of action is uncertain. A previous study indicates that the transcriptional regulation and post-translational modification of P53 occur simultaneously during DNA damage, nevertheless, the post-translational modification of P53, including protein phosphorylation and ubiquitination, is a faster and more sensitive means of P53 protein level regulation than transcriptional control [43]. $p 53$ mRNA expression is controlled by various transcriptional regulators including microRNAs, $p 53$ anti-sense RNA wrap, and epigenetic regulation [44]. Moreover, during DNA damage, post-transcriptional and post-translational modifications interfere with P53 protein expression and stability. The post-transcriptional regulation of P53 by various RNA-binding proteins is essential for the modulation of P53 activity. Earlier studies show that RNA-binding proteins promote [45] or repress [46] P53 translation by binding to the $5^{\prime}$ or $3^{\prime}$ untranslated regions of $p 53$ mRNA. Post-translational modifications including P53-MDM2 protein interaction [47] and P53 phosphorylation [48] regulate P53 stabilization and degradation. MDM2, a P53-specific E3 ubiquitin ligase, restricts P53-mediated growth suppression in unstressed cells [49]. Radiation-induced Ser-15 phosphorylation in P53 [50] prevents P53 proteasomal degradation from MDM2 and P53 interaction [51]. The aforementioned results suggest that transcriptional, post-transcriptional, and post-translational regulation are possibly involved in controlling flavopereirine-mediated P53 expression, but the detailed mechanisms involved remain to be determined.

Flavopereirine significantly reduced cell viability and enhanced apoptosis in both wild type and mutant CRC cells harboring functional P53 expression. On the other hand, it had no such influences on nonfunctional P53-expressing CRC cells. Conventional chemotherapies against advanced 
CRC raise P53 activity, arrest the cell cycle, inhibit DNA replication, and cause cell death [52]. P53 mutation is observed in $\sim 35 \%$ to $40 \%$ of all CRC cases. The efficacies of chemotherapy [53] and radiotherapy [54] are significantly reduced by mutations in the DNA-binding domain, which results in P53 protein conformational change and decreases the transcriptional activity of P53, as these diminish the interaction between P53 and DNA. Therefore, restoration of normal P53 function and expression can sensitize CRC to these therapies. Missense P53 mutations are associated with conformational change and cause the accumulation of misfolded protein in the nucleus. Thus, P53 reactivation is an effective cancer therapy strategy. An earlier study reveals that treatment with the mutant P53 activator chetomin causes P53 to refold into a wild type-like conformation and induces apoptosis in various cancer cells [27]. Furthermore, the reactivation of P53 and the induction of tumor cell apoptosis (RITA) binds P53, blocks its interaction with MDM2, enhances and stabilizes the capacity of P53 to induce apoptosis, suppresses cancer cell growth [28,55], and may sensitize CRC cells to chemotherapy [26]. Flavopereirine could selectively treat CRC bearing functional—but not nonfunctional-p53 expression. However, it is still unclear as to how flavopereirine induces apoptosis in mutant P53-expressing CRC cells by causing a conformational change in mutant P53, enhancement of net P53 function, and upregulation of the mutant P53 protein level.

Kras mutations occur in $\sim 35 \%$ to $40 \%$ of all CRC cases [56]. Kras mutations in CRC are predictive markers for anti-epidermal growth factor receptor therapy resistance $[57,58]$ and clinical responsive markers for platin-based treatment. Therefore, Kras status is crucial in CRC therapy. Our data indicated that flavopereirine reduced the viability of Kras wild type (HT-29) and Kras mutant (SW480, SW620, DLD1, and HCT116) cells. Moreover, a previous study discloses that the both Kras wild type and mutant non-small lung cancer cells are sensitive to the $\beta$-carboline alkaloid krukovine which mediates growth suppression [59]. This finding is consistent with our results and suggests that $\beta$-carboline alkaloids, such as flavopereirine, exhibit great potential to treat CRC bearing wild type and mutant Kras [59].

\section{Materials and Methods}

\subsection{Cell Culture}

The CRC cell lines SW1116, SW480, SW620, DLD1, HT29, and $\mathrm{CaCO}_{2}$ were purchased from the Bioresource Collection and Research Center (BCRC; Hsinchu, Taiwan). SW1116, SW480 and SW620 cells were cultured in Leibovitz L-15 Medium (Life Technologies, Grand Island, NY, USA). HT29 and DLD1 cells were cultured in high-glucose Dulbecco's modified Eagle's medium (Invitrogen, Carlsbad, CA, USA). $\mathrm{CaCO}_{2}$ cells were cultured in Eagle's minimum essential medium (Invitrogen). Wild type HCT116 $\left(p 53^{+/+}\right)$cells and isogenic $p 53$ null cells (HCT116 $\left.\left(p 53^{-/}\right)\right)$were purchased from Horizon Discovery Group (Cambridge, UK) [60] and cultured in RPMI 1640 medium (Invitrogen). All media were supplemented with $10 \%$ fetal bovine serum (FBS; Invitrogen) and antibiotics (100 $\mathrm{U} \mathrm{mL}^{-1}$ penicillin and $100 \mathrm{mg} \mathrm{mL}^{-1}$ streptomycin) according to the manufacturer's instructions.

\subsection{Flavopereirine}

Flavopereirine (CAS Number 70128-63-1) with molecular formula $\left(\mathrm{C}_{17} \mathrm{H}_{15} \mathrm{~N}_{2} \mathrm{ClO}_{4}\right)$ and molecular weight $(346.76 \mathrm{~g} / \mathrm{moL})$ was obtained from ChromaDex (Irvine, CA, USA). After purchasing, flavopereirine was dissolved with dimethyl sulfoxide and stored at $-20^{\circ} \mathrm{C}$. Furthermore, the dissolved flavopereirine was diluted in complete cell culture medium for experiments.

\subsection{Viability Assay}

CRC cell lines $\left(5 \times 10^{3}\right.$ well $\left.^{-1}\right)$ were seeded in a 96 -well plate and treated with various concentrations of flavopereirine in culture medium for $24 \mathrm{~h}$ and $48 \mathrm{~h}$. Then the cell proliferation reagent WST-1 (Roche Applied Science, Penzberg, Germany) was added to determine cell viability [61]. 


\subsection{Apoptosis Assay}

Fluorescein isothiocyanate (FITC)-labeled annexin-V and propidium iodide (PI) (BD Biosciences Inc., San Jose, CA, USA) were applied as a double stain to evaluate flavopereirine-induced apoptosis. CRC cells were treated with various concentrations of flavopereirine in culture medium for $48 \mathrm{~h}$, washed and stained with annexin V-FITC and PI, and analyzed by flow cytometry. The percentage of annexin-V-positive (early apoptosis) and annexin-V + PI-positive (late apoptosis) cells was calculated in CellQuest (BD Biosciences Inc., San Jose, CA, USA).

\subsection{Western Blotting Analysis}

The effects of flavopereirine on protein expression and phosphorylation, apoptosis, cell cycle, and signal transduction were verified by western blotting using specific antibodies. CRC cells were seeded in culture plates, treated with various concentrations of flavopereirine for $24 \mathrm{~h}$ and $48 \mathrm{~h}$, and lysed. Cellular protein was then extracted and quantified. Equal concentrations of cellular protein $(20 \sim 30 \mu \mathrm{g})$ were subjected to SDS-PAGE electrophoresis for western blotting. Antibodies against P21 (1:2000), cyclin B1 (1:1000), Bcl-2 (1:1000), cdc2 (1:1000), Ser-10 phosphorylated histone H3 (pHH3) (1:1000), and histone H3 (1:3000) were purchased from Santa Cruz Biotechnology (Dallas, TX, USA) and used to reveal cell cycle progression. Antibodies against caspase-3 (1:2000), -8 (1:2000), -9 (1:2000), PARP (1:2,000), cleaved caspase-3 (1:1000), -8 (1:1000), and -9 (1:1000), cleaved PARP (1:1000), Mcl-1 (1:1000), Bid (1:1000), and Bim (1:1000) were purchased from Cell Signaling Technology (Danvers, MA, USA) and used to determine cellular apoptosis. The following were applied to disclose flavopereirine-affected signal transduction pathways: antibodies against P53 (1:2000) (Santa Cruz Biotechnology, Dallas, TX, USA), Ser-15 phosphorylated P53 (1:1000) (pP53; Cell Signaling Technology, Danvers, MA, USA), Tyr-1007/1008 phosphorylated JAK2 (1:2000) (pJak2; Cell Signaling Technology, Danvers, MA, USA), JAK2 (1:4000) (Cell Signaling Technology, Danvers, MA, USA), Tyr-701 phosphorylated STAT1 (1:2000) (pSTAT1; Cell Signaling Technology, Danvers, MA, USA), STAT1 (1:4000) (Epitomics, Burlingame, CA, USA), Tyr-705 phosphorylated STAT3 (1:2000) (pSTAT3; Cell Signaling Technology, Danvers, MA, USA), STAT3 (1:1000) (Cell Signaling Technology, Danvers, MA, USA), and c-Myc (1:1000) (Cell Signaling Technology, Danvers, MA, USA). Anti- $\beta$-actin antibody (1:5000) (Santa Cruz Biotechnology, Dallas, TX, USA) served as a loading control.

\subsection{Cell Cycle Analysis}

PI (BD Biosciences Inc., San Jose, CA, USA) staining was used to verify the effects of flavopereirine on CRC cell cycle progression. CRC cells were starved in serum-free medium for $24 \mathrm{~h}$ to synchronize their cell cycles, treated with various concentrations of flavopereirine for $24 \mathrm{~h}$, collected and fixed for PI staining, and analyzed by flow cytometry. The percentage of cells in G1, S, and G2/M was determined in ModFit (BD Biosciences Inc., San Jose, CA, USA).

\subsection{Enforced Expression of Constitutive Active STAT3 (cSTAT3) and c-Myc in CRC Cells}

The lentivirus-based constitutive active stat3 (cstat3)-expressing plasmid pcstat3 (EF.STAT3C.Ubc.GFP, 24983) was purchased from addgene (Watertown, MA, USA). To generate viral particles, pcstat3 was transfected into HEK293T cells. The cSTAT3-expressing lentiviral supernatant was collected [62] and used to infect the CRC cells. The green fluorescence protein (GFP) -positive CRC cells were separated and used in subsequent experiments.

The c-Myc expressing plasmid pc-myc (pcDNA3-myc, 16011) purchased from addgene (Watertown, MA, USA) was applied to induce c-Myc overexpression in CRC cells. The $p c-m y c$ plasmid was transiently transfected into HCT116 [63]. Both cSTAT3- and c-Myc-overexpressing HCT116 cells were treated with flavopereirine for $48 \mathrm{~h}$. The cell proliferation reagent WST-1 (Roche Applied Sciences, Penzberg, Germany) was added to determine cell viability. 


\subsection{In Vivo Tumor Growth Assay}

To evaluate the effects of flavopereirine on CRC growth in vivo, male mice with severe combined immunodeficiency (eight weeks; BioLASCO, Taipei, Taiwan) were used with the approval of the Institutional Animal Care and Use Committee of Chang Gung Memorial Hospital (Chiayi, Taiwan). Briefly, HCT116 cells $\left(10^{6}\right)$ were subcutaneously injected into the mice. Mice bearing tumors $\left(\sim 100 \mathrm{~mm}^{3}\right.$ volume) were assigned to PBS or flavopereirine $\left(10 \mathrm{mg} \mathrm{kg}^{-1}\right.$ mouse $\left.^{-1}\right)$ treatment groups. The materials were injected intraperitoneally once daily. Tumor volume was measured every $3 \mathrm{~d}$ and was not allowed to grow over $2000 \mathrm{~mm}^{3}$. After $21 \mathrm{~d}$, the tumors were harvested, photographed, fixed, and frozen for future analysis.

\subsection{Immunohistochemical and Immunofluorescent TUNEL Staining Assays of HCT116-Xenograft Tumor}

Immunohistochemical staining assays were performed as described in a previous study [64]. Briefly, HCT116 tumor sections (diameter $10 \mu \mathrm{m}$ ) were stained with rabbit anti-P53 and anti-P21 antibodies (Santa Cruz Biotechnology, Dallas, TX, USA). An immunofluorescent TUNEL-staining kit (No. 11767291910; Sigma-Aldrich Corp., St Louis, MO, USA) was used to detect apoptosis in the CRC-xenograft tumor according to the manufacturer's (Roche Applied Science, Penzberg, Germany) instructions. DAPI (4',6-diamidino-2-phenylindole) nuclear staining served as a counterstaining control. TUNEL-positive cells were quantified at five randomly selected fields $(\times 400$ magnification $)$ per tissue slide in quintuplicate assays (ImageJ; NIH, Bethesda, MD, USA). Furthermore, the morphology of colon tissue sections was examined by pathologist.

\subsection{Statistical Analyses}

GraphPad Prism v. 5 (GraphPad Software, La Jolla, CA, USA) was used to perform the data analyses. Data were presented as means \pm standard deviation (SD). Statistically significant differences between one group were assessed by unpaired Student's $t$-tests. Differences between more than two groups were compared by two-way analysis of variance and following Bonferroni post hoc test, with values of $p$ less than 0.05 considered statistically significant.

\section{Conclusions}

The molecular mechanism by which flavopereirine reduced cell viability, arrested the cell cycle, and induced apoptosis in CRC was proposed in supplementary Figure S4. The present study revealed that flavopereirine activated P53-P21, rather than JAKs-STSTs-cMyc signaling, to suppress CRC cell growth through the extrinsic and intrinsic apoptotic pathways and G2/M-phase cell cycle arrest.

Supplementary Materials: The following are available online at http://www.mdpi.com/2072-6694/11/7/1034/s1, Figure S1: Oxaliplatin reduced the viability of various CRC cell lines, Figure S2: P53 signaling was involved in flavopereirine-mediated viability reduction and apoptosis induction in truncated and nonfunctional P53-expressing CRC cells, Figure S3: Flavopereirine treatment did not significantly change the integrity of normal colon tissue in mouse in vivo, Figure S4: Proposed mechanisms of flavopereirine in cell cycle distribution and apoptosis for affecting CRC cell growth regulation.

Author Contributions: J.-M.L. designed and performed the research and wrote the paper. Chih-Chien Chin (C.-C.C.) and C.-S.S. wrote the paper and supervised the research. Chih-Chung Cheng (C.-C.C.) and Y.-H.K. performed the in vitro experiments. Y.-C.H., F.-C.K. and S.-F.C. contributed in interpreting the results on the manuscript. Y.-R.L. conceived the original idea and contributed to the final version of the manuscript.

Funding: This study was funded by the Research Project of Chang Gung Memorial hospital at Chiayi, Taiwan (CMRPG6F0581-3 and CMRPG6G0291) and the Ministry of Science and Technology, Taiwan (MOST103-2314-B-182A-105 and MOST105-2314-B-182A-096).

Acknowledgments: The authors thank the Laboratory Animal Center of Chang Gung Memorial Hospital, Chiayi, Taiwan for providing the facilities and animal care required for this study. We also thank the personnel of the Flow Cytometer Room of the Department of Medical Research of Chang Gung Memorial Hospital, Chiayi, Taiwan for assisting with flow cytometry.

Conflicts of Interest: The authors declare no conflicts of interest. 


\section{References}

1. Favoriti, P.; Carbone, G.; Greco, M.; Pirozzi, F.; Pirozzi, R.E.; Corcione, F. Worldwide burden of colorectal cancer: A review. Updates Surg. 2016, 68,7-11. [CrossRef] [PubMed]

2. Karapetis, C.S.; Khambata-Ford, S.; Jonker, D.J.; O'Callaghan, C.J.; Tu, D.; Tebbutt, N.C.; Simes, R.J.; Chalchal, H.; Shapiro, J.D.; Robitaille, S.; et al. K-ras mutations and benefit from cetuximab in advanced colorectal cancer. N. Engl. J. Med. 2008, 359, 1757-1765. [CrossRef] [PubMed]

3. Sun, X.; Wang, X.; Feng, W.; Guo, H.; Tang, C.; Lu, Y.; Xiang, X.; Bao, Y. Gene signatures associated with drug resistance to irinotecan and oxaliplatin predict a poor prognosis in patients with colorectal cancer. Oncol. Lett. 2017, 13, 2089-2096. [CrossRef] [PubMed]

4. Bardhan, K.; Liu, K. Epigenetics and colorectal cancer pathogenesis. Cancers 2013, 5, 676-713. [CrossRef]

5. Brenner, H.; Kloor, M.; Pox, C.P. Colorectal cancer. Lancet 2014, 383, 1490-1502. [CrossRef]

6. Kinzler, K.W.; Vogelstein, B. Lessons from hereditary colorectal cancer. Cell 1996, 87, 159-170. [CrossRef]

7. Fearon, E.R. Molecular genetics of colorectal cancer. Annu. Rev. Pathol. 2011, 6, 479-507. [CrossRef]

8. Slattery, M.L.; Lundgreen, A.; Kadlubar, S.A.; Bondurant, K.L.; Wolff, R.K. JAK/STAT/SOCS-signaling pathway and colon and rectal cancer. Mol. Carcinog. 2013, 52, 155-166. [CrossRef]

9. Yu, H.; Lee, H.; Herrmann, A.; Buettner, R.; Jove, R. Revisiting STAT3 signalling in cancer: New and unexpected biological functions. Nat. Rev. Cancer 2014, 14, 736-746. [CrossRef]

10. Schindler, C.W. Series introduction. JAK-STAT signaling in human disease. J. Clin. Investig. 2002, 109, $1133-1137$. [CrossRef]

11. Zhong, Z.; Wen, Z.; Darnell, J.E., Jr. Stat3: A STAT family member activated by tyrosine phosphorylation in response to epidermal growth factor and interleukin-6. Science 1994, 264, 95-98. [CrossRef] [PubMed]

12. Ihle, J.N. The Stat family in cytokine signaling. Curr. Opin. Cell Biol. 2001, 13, 211-217. [CrossRef]

13. Yu, H.; Kortylewski, M.; Pardoll, D. Crosstalk between cancer and immune cells: Role of STAT3 in the tumour microenvironment. Nat. Rev. Immunol. 2007, 7, 41-51. [CrossRef] [PubMed]

14. Siveen, K.S.; Sikka, S.; Surana, R.; Dai, X.; Zhang, J.; Kumar, A.P.; Tan, B.K.; Sethi, G.; Bishayee, A. Targeting the STAT3 signaling pathway in cancer: Role of synthetic and natural inhibitors. Biochim. Biophys. Acta 2014, 1845, 136-154. [CrossRef] [PubMed]

15. Zushi, S.; Shinomura, Y.; Kiyohara, T.; Miyazaki, Y.; Kondo, S.; Sugimachi, M.; Higashimoto, Y.; Kanayama, S.; Matsuzawa, Y. STAT3 mediates the survival signal in oncogenic ras-transfected intestinal epithelial cells. Int. J. Cancer 1998, 78, 326-330. [CrossRef]

16. Rahaman, S.O.; Harbor, P.C.; Chernova, O.; Barnett, G.H.; Vogelbaum, M.A.; Haque, S.J. Inhibition of constitutively active Stat 3 suppresses proliferation and induces apoptosis in glioblastoma multiforme cells. Oncogene 2002, 21, 8404-8413. [CrossRef] [PubMed]

17. Spitzner, M.; Roesler, B.; Bielfeld, C.; Emons, G.; Gaedcke, J.; Wolff, H.A.; Rave-Frank, M.; Kramer, F.; Beissbarth, T.; Kitz, J.; et al. STAT3 inhibition sensitizes colorectal cancer to chemoradiotherapy in vitro and in vivo. Int. J. Cancer 2014, 134, 997-1007. [CrossRef] [PubMed]

18. Vogelstein, B.; Lane, D.; Levine, A.J. Surfing the p53 network. Nature 2000, 408, 307-310. [CrossRef]

19. Takayama, T.; Miyanishi, K.; Hayashi, T.; Sato, Y.; Niitsu, Y. Colorectal cancer: Genetics of development and metastasis. J. Gastroenterol. 2006, 41, 185-192. [CrossRef]

20. Kuerbitz, S.J.; Plunkett, B.S.; Walsh, W.V.; Kastan, M.B. Wild-type p53 is a cell cycle checkpoint determinant following irradiation. Proc. Natl. Acad. Sci. USA 1992, 89, 7491-7495. [CrossRef]

21. Lowe, S.W.; Schmitt, E.M.; Smith, S.W.; Osborne, B.A.; Jacks, T. p53 is required for radiation-induced apoptosis in mouse thymocytes. Nature 1993, 362, 847-849. [CrossRef] [PubMed]

22. Karimian, A.; Ahmadi, Y.; Yousefi, B. Multiple functions of p21 in cell cycle, apoptosis and transcriptional regulation after DNA damage. DNA Repair 2016, 42, 63-71. [CrossRef] [PubMed]

23. El-Deiry, W.S. Regulation of p53 downstream genes. Semin. Cancer Biol. 1998, 8, 345-357. [CrossRef] [PubMed]

24. Mihara, M.; Erster, S.; Zaika, A.; Petrenko, O.; Chittenden, T.; Pancoska, P.; Moll, U.M. p53 has a direct apoptogenic role at the mitochondria. Mol. Cell 2003, 11, 577-590. [CrossRef]

25. Robles, A.I.; Jen, J.; Harris, C.C. Clinical Outcomes of TP53 Mutations in Cancers. Cold Spring Harb Perspect. Med. 2016, 6. [CrossRef] 
26. Wiegering, A.; Matthes, N.; Muhling, B.; Koospal, M.; Quenzer, A.; Peter, S.; Germer, C.T.; Linnebacher, M.; Otto, C. Reactivating p53 and Inducing Tumor Apoptosis (RITA) Enhances the Response of RITA-Sensitive Colorectal Cancer Cells to Chemotherapeutic Agents 5-Fluorouracil and Oxaliplatin. Neoplasia 2017, 19, 301-309. [CrossRef] [PubMed]

27. Hiraki, M.; Hwang, S.Y.; Cao, S.; Ramadhar, T.R.; Byun, S.; Yoon, K.W.; Lee, J.H.; Chu, K.; Gurkar, A.U.; Kolev, V.; et al. Small-Molecule Reactivation of Mutant p53 to Wild-Type-like p53 through the p53-Hsp40 Regulatory Axis. Chem. Biol. 2015, 22, 1206-1216. [CrossRef]

28. Issaeva, N.; Bozko, P.; Enge, M.; Protopopova, M.; Verhoef, L.G.; Masucci, M.; Pramanik, A.; Selivanova, G. Small molecule RITA binds to p53, blocks p53-HDM-2 interaction and activates p53 function in tumors. Nat. Med. 2004, 10, 1321-1328. [CrossRef]

29. Hughes, N.A.; Rapoport, H. Flavopereirine, an Alkaloids from Geissospermum vellosii. J. Am. Chem. Soc. 1958, 80, 1604-1609. [CrossRef]

30. Beljanski, M.; Beljanski, M.S. Selective inhibition of in vitro synthesis of cancer DNA by alkaloids of beta-carboline class. Exp. Cell Biol. 1982, 50, 79-87. [CrossRef]

31. Beljanski, M. The anticancer agent PB-100, selective active on malignant cells, inhibits multiplication of sixteen malignant cell lines, evenmultidrug resistant. Genet. Mol. Biol. 2000, 20, 29-33. [CrossRef]

32. Beljanski, M.; Crochet, S.; Beljanski, M.S. PB-100: A potent and selective inhibitor of human BCNU resistant glioblastoma cell multiplication. Anticancer Res. 1993, 13, 2301-2308. [PubMed]

33. Beljanski, M.; Crochet, $\mathrm{S}$. The selective anticancer agent pb-100 inhibits interleukin-6 induced enhancement of glioblastoma cell-proliferation in-vitro. Int. J. Oncol. 1994, 5, 873-879. [CrossRef] [PubMed]

34. Innocente, S.A.; Abrahamson, J.L.; Cogswell, J.P.; Lee, J.M. p53 regulates a G2 checkpoint through cyclin B1. Proc. Natl. Acad. Sci. USA 1999, 96, 2147-2152. [CrossRef] [PubMed]

35. Hans, F.; Dimitrov, S. Histone H3 phosphorylation and cell division. Oncogene 2001, 20, 3021-3027. [CrossRef] [PubMed]

36. Wang, X.W.; Harris, C.C. p53 tumor-suppressor gene: Clues to molecular carcinogenesis. J. Cell Physiol. 1997, 173, 247-255. [CrossRef]

37. Djelloul, S.; Forgue-Lafitte, M.E.; Hermelin, B.; Mareel, M.; Bruyneel, E.; Baldi, A.; Giordano, A.; Chastre, E.; Gespach, C. Enterocyte differentiation is compatible with SV40 large T expression and loss of p53 function in human colonic Caco-2 cells. Status of the pRb1 and pRb2 tumor suppressor gene products. FEBS Lett. 1997, 406, 234-242. [CrossRef]

38. Torre, L.A.; Bray, F.; Siegel, R.L.; Ferlay, J.; Lortet-Tieulent, J.; Jemal, A. Global cancer statistics, 2012. CA Cancer J. Clin. 2015, 65, 87-108. [CrossRef]

39. Baba, K.; Oshita, A.; Kohyama, M.; Inoue, S.; Kuroo, Y.; Yamaguchi, T.; Nakamura, H.; Sugiyama, Y.; Tazaki, T.; Sasaki, M.; et al. Successful treatment of conversion chemotherapy for initially unresectable synchronous colorectal liver metastasis. World J. Gastroenterol. 2015, 21, 1982-1988. [CrossRef]

40. Chan, K.M.; Wu, T.H.; Cheng, C.H.; Lee, W.C.; Chiang, J.M.; Chen, J.S.; Wang, J.Y. Prognostic significance of the number of tumors and aggressive surgical approach in colorectal cancer hepatic metastasis. World J. Surg. Oncol. 2014, 12, 155. [CrossRef]

41. Li, J.; Liu, Y.Y.; Yang, X.F.; Shen, D.F.; Sun, H.Z.; Huang, K.Q.; Zheng, H.C. Effects and mechanism of STAT3 silencing on the growth and apoptosis of colorectal cancer cells. Oncol. Lett. 2018, 16, 5575-5582. [CrossRef] [PubMed]

42. Dutta, A.; Ruppert, J.M.; Aster, J.C.; Winchester, E. Inhibition of DNA replication factor RPA by p53. Nature 1993, 365, 79-82. [CrossRef] [PubMed]

43. Kastan, M.B.; Onyekwere, O.; Sidransky, D.; Vogelstein, B.; Craig, R.W. Participation of p53 protein in the cellular response to DNA damage. Cancer Res. 1991, 51, 6304-6311. [CrossRef] [PubMed]

44. Saldana-Meyer, R.; Recillas-Targa, F. Transcriptional and epigenetic regulation of the p53 tumor suppressor gene. Epigenetics 2011, 6, 1068-1077. [CrossRef] [PubMed]

45. Mazan-Mamczarz, K.; Galban, S.; Lopez de Silanes, I.; Martindale, J.L.; Atasoy, U.; Keene, J.D.; Gorospe, M. RNA-binding protein HuR enhances p53 translation in response to ultraviolet light irradiation. Proc. Natl. Acad. Sci. USA 2003, 100, 8354-8359. [CrossRef]

46. Takagi, M.; Absalon, M.J.; McLure, K.G.; Kastan, M.B. Regulation of p53 translation and induction after DNA damage by ribosomal protein L26 and nucleolin. Cell 2005, 123, 49-63. [CrossRef] [PubMed]

47. Haupt, Y.; Maya, R.; Kazaz, A.; Oren, M. Mdm2 promotes the rapid degradation of p53. Nature 1997, 387, $296-299$. [CrossRef] [PubMed] 
48. Loughery, J.; Cox, M.; Smith, L.M.; Meek, D.W. Critical role for p53-serine 15 phosphorylation in stimulating transactivation at p53-responsive promoters. Nucleic Acids Res. 2014, 42, 7666-7680. [CrossRef]

49. Moll, U.M.; Petrenko, O. The MDM2-p53 interaction. Mol. Cancer Res. 2003, 1, 1001-1008.

50. Canman, C.E.; Lim, D.S.; Cimprich, K.A.; Taya, Y.; Tamai, K.; Sakaguchi, K.; Appella, E.; Kastan, M.B.; Siliciano, J.D. Activation of the ATM kinase by ionizing radiation and phosphorylation of p53. Science 1998, 281, 1677-1679. [CrossRef]

51. Siliciano, J.D.; Canman, C.E.; Taya, Y.; Sakaguchi, K.; Appella, E.; Kastan, M.B. DNA damage induces phosphorylation of the amino terminus of p53. Genes Dev. 1997, 11, 3471-3481. [CrossRef] [PubMed]

52. Yaffee, P.; Osipov, A.; Tan, C.; Tuli, R.; Hendifar, A. Review of systemic therapies for locally advanced and metastatic rectal cancer. J. Gastrointest. Oncol. 2015, 6, 185-200. [CrossRef] [PubMed]

53. Longley, D.B.; Boyer, J.; Allen, W.L.; Latif, T.; Ferguson, P.R.; Maxwell, P.J.; McDermott, U.; Lynch, M.; Harkin, D.P.; Johnston, P.G. The role of thymidylate synthase induction in modulating p53-regulated gene expression in response to 5-fluorouracil and antifolates. Cancer Res. 2002, 62, 2644-2649. [PubMed]

54. Skinner, H.D.; Sandulache, V.C.; Ow, T.J.; Meyn, R.E.; Yordy, J.S.; Beadle, B.M.; Fitzgerald, A.L.; Giri, U.; Ang, K.K.; Myers, J.N. TP53 disruptive mutations lead to head and neck cancer treatment failure through inhibition of radiation-induced senescence. Clin. Cancer Res. 2012, 18, 290-300. [CrossRef] [PubMed]

55. Grinkevich, V.V.; Nikulenkov, F.; Shi, Y.; Enge, M.; Bao, W.; Maljukova, A.; Gluch, A.; Kel, A.; Sangfelt, O.; Selivanova, G. Ablation of key oncogenic pathways by RITA-reactivated p53 is required for efficient apoptosis. Cancer Cell 2009, 15, 441-453. [CrossRef] [PubMed]

56. Brand, T.M.; Wheeler, D.L. KRAS mutant colorectal tumors: Past and present. Small GTPases 2012, 3, 34-39. [CrossRef] [PubMed]

57. Siddiqui, A.D.; Piperdi, B. KRAS mutation in colon cancer: A marker of resistance to EGFR-I therapy. Ann. Surg. Oncol. 2010, 17, 1168-1176. [CrossRef] [PubMed]

58. Knickelbein, K.; Zhang, L. Mutant KRAS as a critical determinant of the therapeutic response of colorectal cancer. Genes Dis. 2015, 2, 4-12. [CrossRef]

59. Lai, H.; Wang, Y.; Duan, F.; Li, Y.; Jiang, Z.; Luo, L.; Liu, L.; Leung, E.L.H.; Yao, X. Krukovine Suppresses KRAS-Mutated Lung Cancer Cell Growth and Proliferation by Inhibiting the RAF-ERK Pathway and Inactivating AKT Pathway. Front. Pharmacol. 2018, 9, 958. [CrossRef]

60. Boyer, J.; McLean, E.G.; Aroori, S.; Wilson, P.; McCulla, A.; Carey, P.D.; Longley, D.B.; Johnston, P.G. Characterization of p53 wild-type and null isogenic colorectal cancer cell lines resistant to 5-fluorouracil, oxaliplatin, and irinotecan. Clin. Cancer Res. 2004, 10, 2158-2167. [CrossRef]

61. Shi, C.S.; Huang, H.C.; Wu, H.L.; Kuo, C.H.; Chang, B.I.; Shiao, M.S.; Shi, G.Y. Salvianolic acid B modulates hemostasis properties of human umbilical vein endothelial cells. Thromb. Res. 2007, 119, 769-775. [CrossRef] [PubMed]

62. Doshi, U.A.; Shaw, J.; Fox, T.E.; Claxton, D.F.; Loughran, T.P.; Kester, M. STAT3 mediates C6-ceramide-induced cell death in chronic lymphocytic leukemia. Signal Transduct. Target. Ther. 2017, 2, 17051. [CrossRef] [PubMed]

63. Reyes-Gonzalez, J.M.; Armaiz-Pena, G.N.; Mangala, L.S.; Valiyeva, F.; Ivan, C.; Pradeep, S.; Echevarria-Vargas, I.M.; Rivera-Reyes, A.; Sood, A.K.; Vivas-Mejia, P.E. Targeting c-MYC in PlatinumResistant Ovarian Cancer. Mol. Cancer Ther. 2015, 14, 2260-2269. [CrossRef] [PubMed]

64. Tsai, Y.S.; Jou, Y.C.; Lee, G.F.; Chen, Y.C.; Shiau, A.L.; Tsai, H.T.; Wu, C.L.; Tzai, T.S. Aberrant prothymosin-alpha expression in human bladder cancer. Urology 2009, 73, 188-192. [CrossRef] [PubMed]

(C) 2019 by the authors. Licensee MDPI, Basel, Switzerland. This article is an open access article distributed under the terms and conditions of the Creative Commons Attribution (CC BY) license (http://creativecommons.org/licenses/by/4.0/). 